\title{
PENGEMBANGAN LKPD BIOLOGI KELAS X SMA BERDASARKAN INVENTARISASI JENIS ORDO ANURA DI LINGKUNGAN UNIVERSITAS BENGKULU
}

\author{
Mega Selpiya ${ }^{1 *}$, Irwandi Ansori ${ }^{1}$, Aceng Ruyani ${ }^{2}$ \\ ${ }^{1}$ Program Studi Pendidikan Biologi Fakultas Keguruan dan Ilmu Pendidikan, Universitas Bengkulu \\ ${ }^{2}$ Program Pasca Sarjana Pendidikan IPA FKIP Universitas Bengkulu \\ Email: megaduta11@gmail.com
}

\begin{abstract}
Abstrak
Penelitian ini bertujuan untuk mengetahui kelayakan Lembar Kerja Peserta Didik (LKPD) yang dikembangkan berdasarkan inventarisasi jenis ordo Anura di lingkungan Universitas Bengkulu (UNIB). Subjek penelitian ini adalah peserta didik kelas X MIPA 2 Sekolah Menengah Atas (SMA) Negeri 4 Kota Bengkulu. Teknik pengumpulan data pada penelitian ini adalah angket (kuisioner). Instrumen yang digunakan adalah lembar angket untuk tiga orang validator (dua orang Dosen Program Studi Pendidikan Biologi dan guru Biologi SMA kelas X), dan lembar keterbacaan untuk peserta didik. Berdasarkan hasil validasi oleh validator, LKPD yang disusun dinilai sangat layak digunakan dengan nilai rata-rata 91,25\%. Hasil uji keterbacaan oleh peserta didik juga memperoleh predikat sangat layak dengan nilai rata-rata 93\%. Berdasarkan hasil uji validitas dan keterbacaan tersebut, LKPD yang dikembangkan ini sangat layak digunakan sebagai bahan ajar materi keanekaragaman hayatil, subtopik keanekaragaman hayati tingkat jenis pada kelas X SMA.
\end{abstract}

Kata kunci: inventarisasi, Lembar Kerja Peserta Didik (LKPD), ordo Anura

\begin{abstract}
The purpose of this study was to determine the feasibility of Student Worksheets (LKPD) were developed based on inventory of Anura orders in the Bengkulu University area (UNIB). The subjects of this study were students of class X MIPA 2 High School 4 Kota Bengkulu. The data collection technique in this study was a questionnaire. The instruments used were questionnaire sheets for three validators (two Biology Education Lecturers and High School Biology teachers in class X), and readability sheets for students. Based on the results of validation by the validator, the compiled LKPD was considered very feasible to use with an average value of 91.68 percent. The readability test results by students also obtained a very decent predicate with an average value of 93 percent. Based on the results of the validity and readability test, the developed Student Worksheets is worthy of being used as teaching for biodiversity topic, subtopics of species diversity in class $\mathrm{X}$ of senior high school.
\end{abstract}

Kata kunci: Anura order, inventory, student worksheet (LKPD) 


\section{PENDAHULUAN}

Indonesia merupakan negara yang kaya dengan keanekaragaman hayati sehingga menjadikan Indonesia sebagai pusat keanekaragaman hayati kedua di dunia setelah Brazil (Nurhayati, 2016). Keanekaragaman hayati yang berlimpah ini dapat dimanfaatkan diberbagai bidang, seperti dibidang ekonomi, ekologi dan pendidikan. Dalam pendidikan keanekaragaman hayati dapat dimanfaatkan sebagai sumber belajar dengan menggunakan pendekatan linkungan. Pembelajaran menggunakan pendekatan lingkungan merupakan konsep pembelajaran yang memanfaatkan lingkungan sebagai sumber belajar. Menurut Prastowo (2011) sumber belajar adalah segala sesuatu termasuk benda, data, fakta, ide, dan mahkluk hidup lainnya yang bisa menimbulkan proses belajar. Misalnya, buku pelajaran, modul, handout, LKS, model, bahan ajar audio bahan ajar interaktif dan sebagainya.

Pemanfaatan lingkungan sebagai sumber belajar dapat menciptakan pembelajaran yang interaktif, inspiratif dan menyenangkan. Permendikbud No.58 Tahun 2014 menyatakan bahwa proses pembelajaran hendaknya dilakukan dengan cara yang interaktif, inspiratif dan menyenangkan, sehingga dapat memotivasi peserta didik untuk aktif dalam proses pembelajaran.

Hasil observasi peneliti saat melaksanakan magang II pada bulan November 2018 di SMAN 4 Kota Bengkulu menunjukan bahwa guru biologi belum menggunakan sumber belajar yang memanfaatkan lingkungan sekitar, melainkan terbatas pada buku dan ringkasan materi, dan tidakadanya pengembangan ataupun penambahan media serta sumber belajar lainnya. Metode pembelajaran yang diterapkan terbatas pada metode ceramah, diskusi dan demonstrasi. Kondisi ini cenderung menjadikan proses pembelajaran berpusat pada guru (teacher centered). Sedangkan didalam kurikulum 2013 menuntut pembelajaran berpusat pada peserta didik.

Pemanfaatan sumber belajar dari lingkungan sekitar dapat dilakukan apabila dikembangkan menjadi suatu bahan ajar.Sadjati (2012) menyatakan bahwa bahan ajar sangat penting, artinya bagi guru maupun peserta didik dalam proses pembelajaran. Tanpa bahan ajar akan sulit bagi guru untuk meningkatkan efektivitas pembelajaran. Oleh sebab itu, bahan ajar dianggap sebagai bahan yang dapat dimanfaatkan, baik oleh guru maupun peserta didik sebagai salah satu instrumen untuk memperbaiki mutu pembelajaran.

Salah satu bahan ajar yang dapat dibuat oleh guru yaitu Lembar Kerja Peserta Didik (LKPD). LKPD adalah bahan ajar cetak berisi materi, ringkasan, dan petunjukpetunjuk pelaksanaan tugas pembelajaran yang harus dikerjakan oleh peserta didik, yang mengacu pada kompetensi dasar yang harus dicapai (Prastowo, 2011 dan Widyantini, 2013).

Berdasarkan berbagai permasalahan diatas peneliti mengembangkan bahan ajar LKPD berdasarkan sumber belajar yang memanfaatkan potensi lokal di lingkungan Universitas Bengkulu (UNIB). salah satu potensi lokal yang dapat dijadikan sebagai sumber belajar adalah ordo Anura.

Ordo Anura merupakan salah satu ordo hewan vertebrata dari kelas Amfibi. Di Indonesia ordo Anura paling umum dijumpai dan lebih dikenal dengan nama katak atau kodok (Mistar, 2008 dan Mardinata dkk., 2018). Ordo Anura merupakan anggota kelompok Amfibi memiliki ciri khas tidak memiliki ekor (Kurniati, 2014 dan Qurniawan dkk., 2010) 
Berdasarkan hasil penelitianEfriadi (2015) ditemukan 13 jenis spesies ordo Anura dari berbagai sub famili yang tersebar di lingkungan Universitas Bengkulu. Tingginya keragaman ordo Anura tersebut dapat dimanfaatkan sebagai bahan pengembangan LKPD. LKPD ini dibuat untuk materi Keanekaragaman hayati sub bab keanekaragaman hayati tingkat spesies. Adanya LKPD yang didesain dari sumber belajar yang memanfaatkan potensi lokal lingkungan sekitar diharapkan mampu menunjang aktivitas belajar peserta didik sesuai kompetensi yang diharapkan pada pembelajaran materi keanekeragaman hayati.

\section{METODE}

Jenis penelitian yang dilakukan adalah penelitian dan pengembangan (Research and Development (R\&D). Rancangan penelitian yang dilakukan mengadopsi pada langkah-langkah model pengembangan dalam Sugiyono (2012). Model Sugiyono (2012) terdiri dari 10 langkah tetapi dikarenakan keterbatasan waktu peneliti, penelitian ini hanya dilakukan 7 langkah. Adapun langkah-langkah tersebut yaitu: 1). Potensi dan Masalah; 2). Pengumpulan Data; 3). Desain Produk; 4). Validasi Desain;
5). Revisi Desain; 6). Uji Coba Produk; dan 7). Revisi Produk;

Penelitian ini dilaksanakan pada bulan Maret 2019 di SMA Negeri 4 Kota Bengkulu. Subjek uji coba dalam penelitian ini adalah tiga orang validator yang terdiri dari dua orang dosen Pendidikan Biologi Universitas Bengkulu dan satu orang guru biologi SMA Negeri 4 Kota Bengkulu, 30 orang peserta didik kelas X MIPA 2 SMA Negeri 4 Kota Bengkulu. Teknik pengumpulan data dalam penelitian ini menggunakan lembar angket (kuesioner) yang terdiri atas angket uji kelayakan untuk validator (ahli materi, ahli media, dan guru Biologi SMA kelas X), dan angket uji keterbacaan LKPD untuk peserta didik.

Data uji validasi dan uji keterbacaan yang terkumpul dianalisis secara deskriptif kuantitatif. Angka hasil uji yang diperoleh diubah ke dalam persentase kelayakan dengan rumus :

$$
\frac{\text { Jumlah Skor Lembar Validasi }}{\text { Skor Maksimal }} \times 100 \%
$$

Hasil perhitungan persentase kelayakan dan keterbacaan kemudian diinterprestasikan ke dalam kategori kualitatif pada Tabel 1 (Riduwan, 2013)

Tabel 1. Kriteria Interprestasi Skor Uji Validitas

\begin{tabular}{lll}
\hline Presentase & Kriteria Respon Validasi & Kriteria Respon Keterbacaan \\
\hline $0 \%-20 \%$ & Sangat Tidak Valid & Sangat Tidak Layak \\
$21 \%-40 \%$ & Tidak Valid & Tidak Layak \\
$41 \%-60 \%$ & Cukup Valid & Cukup Layak \\
$61 \%-80 \%$ & Valid & Layak \\
$81 \%-100 \%$ & Sangat Valid & Sangat Layak \\
\hline
\end{tabular}

Riduwan (2013)

Lembar Kerja peserta didik dapat dikatakan layak jika persentase skor validasi dan uji keterbacaan yang diperoleh lebih dari $60 \%$.

\section{HASIL DAN PEMBAHASAN}

Berdasarkan hasil analisis data angket validasi LKPD Biologi berdasarkan inventarisasi jenis ordo Anura yang telah dilakukan uji validasi oleh dua Dosen Ahli yaitu Dosen Pendidikan Biologi UNIB, serta 
satu orang guru SMA Negeri 4 Kota Bengkulu. Secara keseluruhan hasil persentase dari tim dosen dan guru disajikan pada Tabel 2.

Tabel 2. Persentase Validasi Oleh Validator

\begin{tabular}{llll}
\hline No & \multicolumn{1}{c}{ Validator } & Persentase & \multicolumn{1}{c}{ Kriteria Respon } \\
\hline 1 & Kelayakan Materi & $90 \%$ & Sangat layak \\
2 & Penyajian Materi & $92 \%$ & Sangat layak \\
3 & Kebahasaan & $93 \%$ & Sangat layak \\
4 & Kegrafisan & $90 \%$ & Sangat layak \\
& Rata-rata Persentase & $91,25 \%$ & Sangat layak \\
\hline
\end{tabular}

Berdasarkan Tabel 2. hasil validasi oleh validator, LKPD hasil pengembangan memiliki rata-rata persentase kelayakan yaitu 90,25 \% menunjukan bahwa LKPD yang dikembangkan layak untuk digunakan sebagai bahan ajar untuk materi keanakeragaman hayati. Validasi LKPD terdiri dari empat aspek yaitu aspek kelayakan isi, penyajian materi, kebahasaan dan kegrafisan. Penilaian ini berdasarkan komponen evaluasi bahan ajar cetak menurut Depdiknas (2008) yaitu meliputi aspek kelayakan isi (materi), kelayakan penyajian, kelayakan kebahasaan, dan kelayakan kegrafisan. Adanya validasi oleh Validator bertujuan untuk mendapatkan LKPD yang layak digunakan sesuai dengan saran dan perbaikan validator. Hal ini sesuai dengan Widarmayati (2015) menyatakan bahwa yang diharapkan dari validasi adalah saran dan perbaikan LKPD. Saran yang diberikan oleh validator adalah acuan untuk perbaikan LKPD.
Desain LKPD yang telah divalidasi oleh validator dinilai layak untuk dijadikan sebagai bahan ajar untuk peserta didik, namun terdapat beberapa poin yang perlu diperbaiki berdasarkan kritik dan saran dari validator, antara lain sebagai berikut :

1. Perbaikan judul pada cover sebaiknya ditambah judul inti kegiatan

2. Perbaikan desain cover LKPD sebaiknya menggunakan foto ordoAnurayang lebih terang dan tidak buram

3. Perbaikan penulisan kalimat agar menggunakan SPOK yang jelas.

4. Perbaikan penulisan imbuhan di dan ke yang menunjukan keterangan tempat atau kata kerja

5. Perbaikan penulisan keterangan gambar

6. Hindari penggunaan gambar yang tidak sesuai dengan LKPD

7. Penambahan tanda seru disetiap kata perintah pada cara kerja

Beberapa perbaikan di atas dapat dilihat pada Gambar 1 dan Gambar 2 .
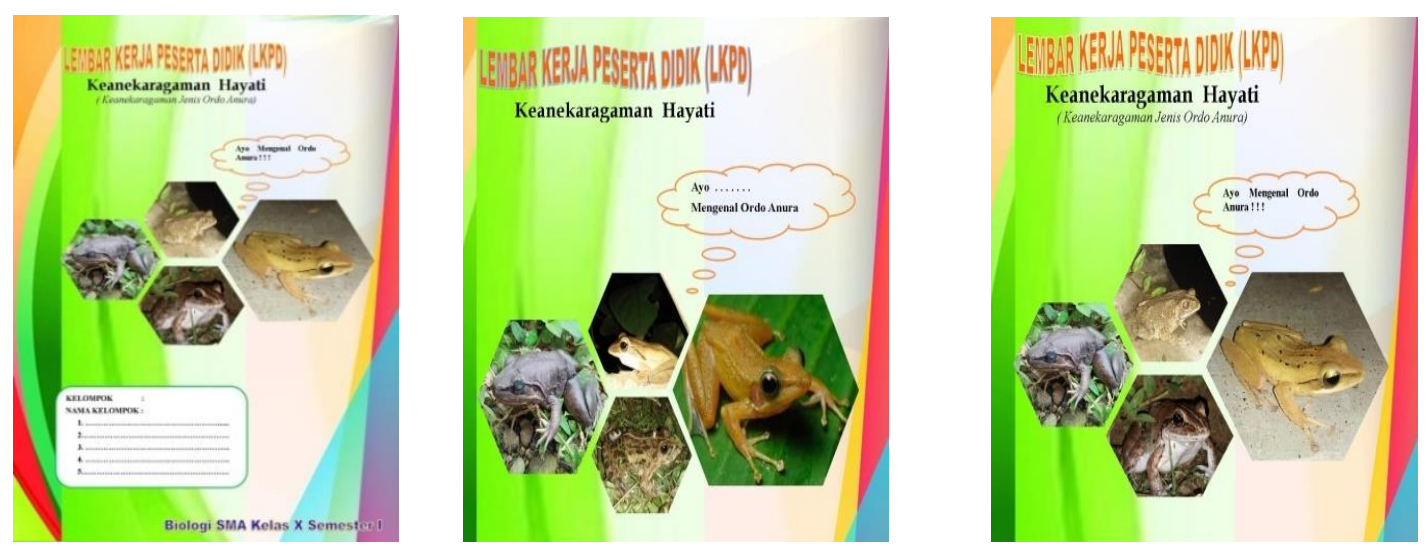

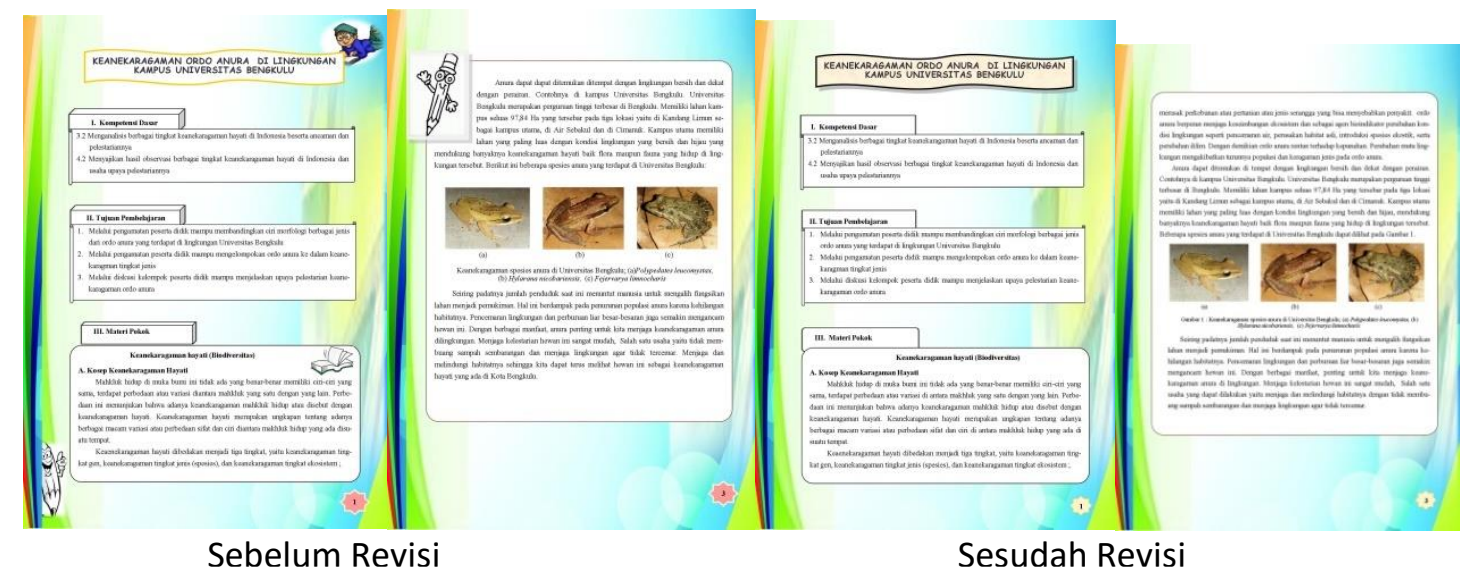

Gambar 2: Perbaikan Gambar yang tidak dibutuhkan LKPD

Berdasarkan saran dan masukan dari validator maka dilakukan revisi desain LKPD. Revisi desain ini bertujuan memperbaiki beberapa kekurangan dalam desain awal LKPD sehingga didapatkan LKPD yang layak digunakan oleh peserta didik.

Setelah desain LKPD direvisi kemudian LKPD dilakukakan uji keterbacaan pada 30 orang peserta didik kelas X MIPA 2 SMA N 4 Kota Bengkulu. Uji keterbacaan dilakukan untuk melihat tingkat keterbacaan dan pemahaman peserta didik terhadap LKPD yang dikembangkan. Apabila hasil uji keterbacaan oleh peserta didik baik maka LKPD yang dikembangkan layak untuk di gunakan oleh peserta didik sebagai bahan ajar (Arikunto, 2013).

Hasil uji keterbacaan oleh peserta didikdapat dilihat pada Tabel 3.

Tabel 3. Hasil Uji keterbacaan Oleh Peserta Didik SMA N 4Kota Bengkulu Terhadap LKPD Keanekaragaman Jenis ordo Anura di Lingkungan Universitas Bengkulu

\begin{tabular}{|c|c|c|c|c|c|}
\hline \multirow{3}{*}{ No. } & \multirow{3}{*}{ Aspek Penilaian } & \multicolumn{4}{|c|}{ Respon Peserta Didik } \\
\hline & & \multicolumn{2}{|c|}{ Ya } & \multicolumn{2}{|c|}{ Tidak } \\
\hline & & $\Sigma$ & $\%$ & $\Sigma$ & $\%$ \\
\hline \multicolumn{6}{|c|}{ Materi } \\
\hline 1 & Materi yang disajikan dalam LKPD mudah dipahami & 29 & 96,6 & 1 & 3,3 \\
\hline 2 & $\begin{array}{l}\text { Materi yang ada dalam LKPD memotivasi saya untuk belajar } \\
\text { mengenai keanekaragaman jenis ordo Anura }\end{array}$ & 28 & 93,3 & 2 & 6,6 \\
\hline 3 & $\begin{array}{l}\text { Wawasan dan pengetahuan saya bertambah melalui materi yang } \\
\text { disajikan pada LKPD }\end{array}$ & 28 & 93,3 & 2 & 6,6 \\
\hline 4 & $\begin{array}{l}\text { Materi yang disajikan pada LKPD dibutuhkan untuk membantu } \\
\text { memahami materi keanekaragaman jenis }\end{array}$ & 28 & 93,3 & 2 & 6,6 \\
\hline \multicolumn{6}{|c|}{ Penyajian } \\
\hline 5 & Judul LKPD disajikan dengan jelas & 29 & 96,6 & 1 & 3,3 \\
\hline 6 & Tujuan pembelajaran pada LKPD dapat dipahami dengan jelas & 27 & 90 & 3 & 10 \\
\hline 7 & Langkah kerja pada LKPD disajikan dengan runtut dan jelas & 29 & 96,6 & 1 & 3,3 \\
\hline 8 & $\begin{array}{l}\text { Kegiatan di dalam LKPD memotivasi untuk berkomunikasi, } \\
\text { berinteraksi dan bekerjasama dengan kelompok. }\end{array}$ & 29 & 96,6 & 1 & 3,3 \\
\hline
\end{tabular}




\begin{tabular}{|c|c|c|c|c|c|}
\hline Keg & $\begin{array}{l}\text { LKPD disusun dengan menggunakan kegiatan ilmiah yang dimulai } \\
\text { dari mengamati, bertanya, mengumpulkan informasi, melakukan } \\
\text { percobaan dan menyimpulkan/ menginformasikan } \\
\text { fisan }\end{array}$ & 28 & 93,3 & 2 & 6,6 \\
\hline 10 & Desain cover sangat menarik dan mewakili isi kegeiatan & 28 & 93,3 & 2 & 6,6 \\
\hline 11 & Gambar dan ilustrasi dalam LKPD ini sesuai dengan materi & 27 & 90 & 3 & 10 \\
\hline 12 & Tabel disajikan dengan jelas dan mudah dipahami & 27 & 90 & 3 & 10 \\
\hline 13 & $\begin{array}{l}\text { Struktur LKPD disusun secara sistematis/ urut sehingga saya mudah } \\
\text { memahami }\end{array}$ & 28 & 93,3 & 2 & 6,6 \\
\hline 14 & Secara keseluruhan desain tampilan sangat menarik & 27 & 90 & 3 & 10 \\
\hline \multicolumn{6}{|c|}{ Kebahasaan } \\
\hline 15 & $\begin{array}{l}\text { Susunan kalimat yang disajikan jelas, sederhana, dan mudah } \\
\text { dimengerti }\end{array}$ & 27 & 90 & 3 & 10 \\
\hline 16 & Bahasa yang digunakan mudah dipahami & 29 & 96,6 & 1 & 3,3 \\
\hline \multirow[t]{2}{*}{17} & Petunjuk dan informasi dalam LKPD jelas & 27 & 90 & 3 & 10 \\
\hline & Rata-rata Persentase & \multicolumn{2}{|c|}{$93 \%$} & \multicolumn{2}{|r|}{ 7\% } \\
\hline
\end{tabular}


Berdasarkan Tabel 3. hasil penilaian uji keterbacaan oleh peserta didik, didapatkan nilai rata-rata persentase $93 \%$ dengan kriteria sangat layak. Berdasarkan hasil uji keterbacaan oleh peserta didik ini, maka LKPD tersebut layak digunakan sebagai bahan ajar pada materi keanekaragaman hayati. Adapun saran dan komentar dari peserta didik antara lain LKPD sebaiknya ditambah butir pertanyaan sehingga menjadi 5 butir pertanyaan, Pertanyaan-pertanyaan juga dibuat lebih sederhana dan mudah dipahami oleh peserta didik. Berdasarkan saran tersebut dilakukan revisi akhir terhadap LKPD sehingga LKPD benar-benar layak digunakan sebagai bahan ajar pada materi keanekaragaman hayati.

Keunggulan utama LKPD hasil pengembangan ini adalahdibuat berdasarkan penelitian dari objek lingkungan sekitar. LKPD dikembangkan berdasarkan hasil penelitian keanekaragaman jenis ordo Anura di lingkungan Universitas Bengkulu. Ordo Anura hasil penelitian dimanfaatkan sebagai media pembelajaran pada LKPD yang dikembangkan.

Adanya pemanfaatan ordo Anura sebagai media dan sumber belajar ini dapat memudahkan peserta didik dalam proses pembelajaran karena peserta didik berhadapan langsung dengan objek atau materi yang dipelajari. Handini (2018) menyatakan bahwa bahan ajar yang berorientasi pada karakteristik dan kearifan lokal suatu daerah lebih memberikan kesan yang nyata dalam pembelajaran sehingga peserta didik mudah memahami materi yang dipelajari. Hal ini didukung oleh pernyataan Zukmadini, dkk (2018) yang menyatakan bahwa keunggulan dari bahan ajar yang berbasis pada kearifan lokal adalah bersifat kontekstual, dekat dengan lingkungan siswa, dan tentunya materi yang disajikan tidak terlepas dari kesesuaian materi yang terdapat pada kurikulum.

Keunggulan lainnya LKPD hasil pengembangan memiliki komponen penyusun yang lengkap, sistematis, dan tersetruktur. Sesuai dengan Depdiknas (2008) LKPD yang baik adalah LKPD yang memiliki komponen penyusun yang lengkap yaitu dimulai dari judul, KD, tujuan, materi/konsep, prosedur kerja dan evaluasi (pertanyaan diskusi diakhiri dengan menyimpulkan).

Desain tampilan LKPD hasil pengembangan lebih menarik, gambar atau ilustrasi disajikan dengan jelas serta didukung dengan pemberian warna sehingga LKPD lebih menarik minat peserta didik. Hal ini dibuktikan dengan hasil penilaian validasi oleh Validator dan peserta didik yang menunjukan hasil di atas nilai minimum. Menurut Salirawati (2004) penampilan LKPD sangat penting karena pertama-tama peserta didik akan lebih tertarik dengan penampilan LKPD tersebut. LKPD yang baik menggunakan lebih banyak ilustrasi dibandingkan dengan kata-kata.

Adanya LKPD hasil pengembangan ini diharapkan mampu membantu guru dalam mengoptimalkan pembelajaran. Penggunaan LKPD diharapkan mampu mengubah kondisi pembelajaran dari yang biasanya guru berperan menentukan apa yang dipelajari menjadi bagaimana menyediakan dan memperkaya pengalaman belajar peserta didik. Pengalaman belajar peserta didik dapat diperoleh melalui serangkaian kegiatan untuk mengeksplorasi lingkungan melalui interaksi aktif dengan teman, lingkungan dan narasumber lainnya. 


\section{PENUTUP}

\section{Simpulan}

Berdasarkan hasil uji validasi kelayakan LKPD oleh validator dan uji keterbacaan oleh peserta didik LKPD yang dikembangkan berdasarkan inventarisasi ordo Anura di lingkungan UNIB dinilai dari aspek kelayakan isi (materi), kebahasaan, penyajian dan kegrafisan dinyatakan layak digunakan sebagai bahan dan media pembelajaran materi keanekaragaman hayati sub bab keanekaragaman tingkat jenis.

\section{Saran}

LKPD hasil pengembangan selanjutnya sebaiknya di emplementasikan pada pembelajaran disekolah kelas X SMA materi Keanekaragaman Hayati sub materi keanekaragaman tingkat jenis untuk memperbaiki proses pembelajaran di kelas atau untuk meningkatkan hasil belajar.

\section{UCAPAN TERIMA KASIH}

Tim peneliti mengucapkan terima kasih khusus kepada Program Penelitian Kerja Sama Luar Negeri (PKLN) Tahun anggaran 2018. No.551/UN30.15/LT/2018 yang telah memberikan dukungan pada penelitian ini.

\section{DAFTAR PUSTAKA}

Arikunto, S. (2013). Prosedur Penelitian: Suatu Pendekatan Praktik. Jakarta: Rineka Cipta.

Depdiknas. (2008). Panduan Pengembangan Bahan Ajar. Jakarta: Direktorat Pembinaan Sekolah Menengah Atas.

Efriadi \& Feri. (2015). Inventarisasi Jenis Amfibi (Ordo Anura) Di Kawasan Kampus Utama Universitas Bengkulu. Skripsi tidak dipublikasikan, Penelitian
Mahasiswa S1, Universitas Bengkulu. Bengkulu.

Handini, M. N. (2018). Studi Etnobotani Tumbuhan Obat Suku Serawai Sebagai Pengembangan Handout Biologi Kelas $X$ SMA. Diklabio $2 \quad(2)$ : 3543.(Online).(http://ejournal.unib.ac/i ndex.php/jppb/article/view/6802/3396 ). Diakses 2 Juli 2019.

Kurniati, Hellen., \& Amir, H. (2014). Karakteristik suara kelompok kodok Microhylidae berubah kecil asal Bali. Jurnal Biologi Indonesia. 10 (2): 159167.(Online).(https://media.neliti.com/ media/publications/77559-id-). Diakses 29 Juni 2019.

Mardinata, R., G. D. Winarno., \& Nurcahyani. (2018). Keanekaragaman Amfibi (Ordo Anura) Di Tipe Habitat. Berbeda Resort Balik Bukit Taman Nasional Bukit Barisan Selatan. Jurnal. 6(1):58-59. (Online).(http://jurnal.fp.unila.ac.id/ind ex.php/jht/article/view/103). Diakses 29 Juni 2019.

Mistar. (2008). Panduan Lapangan Amfibi dan Reptil di Areal Mawas Propinsi Kalimantan Tengah. Medan: Yayasan Penyelamatan Orangutan Borneo.

Nurhayati, N., R. Wijayanti. (2016). Biologi untuk SMA/MA kelas $X$. Bandung : Yrama Widya.

Prastowo, A. (2011). Panduan Kreatif Membuat Bahan Ajar Inovatif. Jogjakarta: Diva Press.

Qurniawan, T. F., Hastin, A. I., \& Rury, E. (2010). Studi Awal Komunitas Ordo Anura di Kawasan Ekowisata Sawangan, Magelang, Jawa Tengah. Jurnal Penelitian. 1 (2) :119-125. 
(Online).(https://journal.bio.unsoed.ac. id/index.php/biosfera/article/view/201 ). Diakses 2 Juli 2019.

Riduwan. (2013). Skala Pengukuran VariabelVariabel Penelitian. Bandung: Alfabeta.

Sadjati, I. M. (2012). Pengembangan Bahan Ajar. Jakarta : Universitas Terbuka.

Salirawati, D. (2004). Penyusunan dan Kegunaan LKS dalam Proses Pembelajaran.(Online).(www.staffnew. uny.ac.id/upload/132001805).Diakses 14 Juli 2019.

Sugiyono. (2012). Metode Penelitian Pendidikan (Pendekatan Kuantitatif, Kualitatif, dan $R$ \& D). Bandung: Alfabeta.

Widarmayanti, R. P., Susantini, E., \& Ambarwati, R. (2015). Profil Validitas LKS Berbasis Keterampilan Proses Pada Subpokok Bahasan Invertebrata Untuk Kelas X SMA. Jurnal Bioedu. 4 (1): 23029528.

(Online). (http://jurnalmahasiswa.unesa.ac.id/in dex.php/bioedu/article/view/10931).

Diakses 29 juni 2019.

Widyantini, T. (2013). Penyusunan Lembar Kegiatan Siswa (LKS) sebagai Bahan Ajar. Yogyakarta : PPPP TK Matematika.

Zukmadini, A. Y., Jumiarni, D., \& Kasrina. (2018). Developingntimicrobial Medicinal Plants Pocketbook Based on Local Wisdom of Muko-Muko and Serawai Ethnics. Jurnal Pendidikan Biologi Indonesia. 4(2):95-104. http://ejournal.umm.ac.id/index.ph p/jpbi/article/view/5436. Diakses 14 Juli 2019. 